\title{
THE IMPACT OF ENTERPRISE RESOURCE PLANNING (ERP) ON THE AUDIT IN THE CONTEXT OF EMERGING TECHNOLOGIES
}

\author{
Mehmet Nuri SALUR ${ }^{1}$ \\ Walaa Khoder KATTAR ${ }^{2}$
}

\begin{abstract}
Companies continue to adopt new tools in light of technology advancements and to maintain their competitive advantage. One of these technologies is the Enterprise Resource Planning (ERP) System. This system integrates all of the company's departments, such as human resources, finance, marketing, and production, into a sophisticated software database that manages and organizes operations. Various studies examine the impact of ERP deployment on the auditing. However, there no paper that compile the results of the recent studies in one reference. The goal of this paper is to provide a comprehensive reference about ERP system and its impact on internal auditing functions. The majority of the data in this report comes from numerous organizational documents and academic studies published since 2011. The results of the study are a presentation of the advantages and disadvantages of using an ERP system for internal auditing process.
\end{abstract}

Keywords: Audit, Enterprise Resource Planning, Emerging Technologies

JEL Codes: M40, M41, M42

\section{GELIŞEN TEKNOLOJILER BAĞLAMINDA KURUMSAL KAYNAK PLANLAMASININ (ERP) DENETIM ÜZERINDEKİ ETKİSI}

Öz

İsletmeler, teknolojik gelişmeler ışığında yeni araçları benimsemeye ve rekabet avantajlarını korumaya devam etmektedirler. Bu gelişen teknolojilerden biri de Kurumsal Kaynak Planlama (ERP) sistemidir. Bu sistem, insan kaynakları, finans, pazarlama ve üretim gibi işletmelerin tüm departmanlarını gelişmiş bir yazılım veri tabanına entegre eden, bu operasyonlar yöneten ve organize eden bir sistemdir. Bu konuda yapılan çeşitli çalışmalar, ERP dağıtımının denetim üzerindeki etkisini de incelemektedir. Ancak yapılan çalışmaların sonuçlarını tek bir çalışmada derleyen bir çalışma bulunmamaktadır. Bu çalışmanın amacı, ERP sistemi ve bunun iç denetim işlevleri üzerindeki etkisi hakkında kapsamlı bir değerlendirme yapmaktır. Bu çalışmadaki verilerin büyük bir kısmı, 2011'den beri yayınlanan çok sayıdaki akademik çalışmalardan elde edilmiştir. Çalışmanın sonuçları, iç denetim süreci için bir ERP sistemi kullanmanın avantaj ve dezavantajlarinı ifade etmektedir.

Anahtar Kelimeler: Denetim, Kurumsal Kaynak Planlaması, Gelişen Teknolojiler

JEL Kodları: M40, M41, M42

\footnotetext{
${ }^{1}$ Ph.D., Assoc. Prof., Necmettin Erbakan University, Faculty of Political Science, Department of Business Administration, nsalur@erbakan.edu.tr,

${ }^{2}$ Ph.D. Candidate, Necmettin Erbakan University, Institute of Social Science, Department of Business Administration, walaakk93.wk@gmail.com,
}

Makalenin Geliş Tarihi (Received Date): 05.12.2021

Revizyon Tarihi (Revised Date): 15.12.2021

Yayına Kabul Tarihi (Acceptance Date): 26.12.2021

Atıf (Citation):Salur, M. N. \& Kattar, W. K. (2021), “The Impact of Enterprise Resource Planning (ERP) on the Audit in the Context of Emerging Technologies”, Ekonomi Maliye İşletme Dergisi, 4(2):115-123 


\section{Introduction}

The world has evolved dramatically during the last few decades. The biggest attention was paid to emerging technologies. Organizations implemented and still implement various technological applications in order to prosper and achieve competitive advantages. Enterprise Resource Planning (ERP) was one of the evolution's outcomes. ERP was not created overnight, but rather as a result of an organizational necessity and subsequent evolution. The first-generation centralized computer systems, which began with the implementation of inventory control packages (IC) in the 1960s, were primarily used to automate inventory control systems.

Material Requirements Planning (MRP) systems were created in the 1970s, and they primarily consisted of planning product or part requirements according to a master production schedule. Manufacturing Resources Planning II (MRP II) was the third generation of revolutionary software systems introduced in the 1980s. MRP II covered topics such as shop floor and distribution management, project management, finance, human resources, and engineering. Enterprise Resource Planning (ERP) systems had the power of enterprise-wide inter-functional coordination and integration until generation four emerged in the late 1980s. During the 1990s, ERP suppliers added new modules and features as "addons" to the core modules, giving rise to "extended ERPs". ERP extensions include advanced planning and scheduling (APS), e-business solutions such as customer relationship management (CRM), and supply chain management (SCM) (Abdullah, 2017).

Ogechi (2018), provided a brief overview of how an ERP system is constructed: An ERP system is a computer system designed to integrate all departments' units and functions into a single computer system capable of meeting the demands of each department. Indeed, the fundamental goal of ERP is to improve information flow across all aspects of a company's internal processes while simultaneously managing the organization. ERP is a collection of distinct but interrelated modules that may be deployed as a complete solution for any organization. The following are the most popular ERP modules, which may be used alone or together to build an integrated system: finance \& Accounting module, Inventory module, production module, sales module, Human Resource Module, SCM Module and finally the CRM module (Abdullah, 2017).

Several studies have been conducted on ERP implementation recently (Schniederjans \& Yadav (2013), Dezdar and Ainin (2011), Ranjan and Pal (2016), Nagpal, Khatri and Kumar (2015) and others ...) However, less research has been done on the effects of ERP on audit functions. This article delves deeper into the impact of ERP in supporting auditing processes, including the advantages and disadvantages of ERP implementation in auditing. The remainder of the report is arranged as follows: Section 2 highlights the evolution of audit and point outs the link between ERP system and audit functions. Section 3 shows the methods used and presents the previous research in the field. Section 4 discusses the results. The paper's summary provides suggestions for future research. It also addresses any limitations that may arise from the particular research.

\section{Background: Link between ERP and auditing}

An audit is simply an examination of a company's records, finances, and physical inventory. It's all about double-checking things, and it's critical to get them right since tax money, government compliance, and company reputation are all on the line (Schenker, 2018). However, how did audit appear and how did it develop? Due to the Industrial Revolution and the consequent increase in corporate activity, auditing processes became widely used. Railroads were important catalysts in the creation of the accounting profession in the United States because of their attempts to record and manage expenses, production, and operating ratios (Chandler, 1977). As businesses began to participate in the stock market, they became conscious of the need for fraud detection and financial accountability systems, and investors began to rely more heavily on financial reporting. Despite the fact that these concerns caused an increase in the use of accounting and auditing systems, auditing did not become mandatory in the United States until after the stock market disaster of 1929. Until fraudulent actions were discovered at McKesson \& Robbins in 1939, audit tasks including a physical examination of stocks and validation of receivables were optional. As a result, in October 1939, the American Institute of Certified Public Accountants (AICPA) issued declaration that required auditors to check the inventory and validate the receivables. As a result, rather than depending on management 
verification processes, auditors were now responsible for inspecting the company entity itself. Even after the introduction of computerized accounting systems in the 1950s, manual auditing methods remained the only option. UNIVAC, for example, was one of the first operational electronic accounting systems in the United States when it was revealed in 1954. Auditors, on the other hand, did not really examine auditing in a computerized setting until the early 1960s (Byrnes et al., 2018). Haskins and Sells introduced AUDITAPE, a card-based computer-aided audit tool (CAAT), in 1967, leading many auditors to explore entering the automated field. From 1968 until the late 1970s, AUDITAPE enabled non-technical auditors to perform more efficient auditing using computers and helped develop several General Audit Software Systems (GAS) (Byrnes et al., 2018). CAATS Core provides features to improve audit effectiveness and efficiency. However, they do not operate $24 / 24$, and thus fail to create a fully persistent audit environment where exceptions and anomalies can be caught as they occur. It also does not work with real-time or near-real-time data streams, and as a result, it is unable to handle undesirable events such as suspected fraud or anomalies in an optimal manner. Additionally, computer-aided auditing entails the deployment of different files across multiple sites, making audits difficult and complicated, especially for those with less technological knowledge. Hence the need for real time and integrated solutions.

However, the procedure for doing this examination differs based on the type of audit being performed. There are four types of audits: internal audits, compilation audits, reviews, and independent audits (Schenker, 2018). The subject of discussion in this article is the impact of ERP on internal audits. So, what Internal audit is about? Internal audit is an audit that anyone in the firm who knows key elements of finance such as generating financial statements, accounting, and how to evaluate internal business processes can perform. Internal audits are performed for a variety of purposes, including ensuring that the numbers in the company's financials add up, as well as to ensure that the company's records are kept correctly, the business's procedures are in order, and that there are properly functioning financial controls (Schenker, 2018). Internal audit is essential. According to the Institute of Internal Auditors corporate governance model, an efficient internal audit is indeed one of the four elements of corporate governance (2005, IIA). Also, it is a precursor to independent audit, and if the firm discovers something improper during an internal audit, it can take corrective action. As a result, an internal audit can assist in making an independent audit operate more smoothly (Schenker, 2018). Internal audit had a share in the technological development that occurred in the field of computers. According to Wang et al. (2013), advances in information technology, in all of its forms, have a quick influence on auditing, and as a result, the ERP system should be viewed as an important element influencing internal audit performance. Audit starts when accounting finishes, According to Kanellou and Spathis (2013), the deployment of ERP systems has been the most significant IT initiative affecting the accounting function in the previous 15 years.

So, what is the link between ERP and internal audit? If internal audit is regarded as a service performed by auditors to ensure that the numbers in the company's financial statements provided by the accountants are not fundamentally misrepresented. And if the ERP system is an integrated program that contains all the company's data, including financial and accounting data. Hence, Auditors rely on data and reports generated by these systems to perform the audit process. What effect does the ERP system have on internal auditing performance in this regard? This research looks at the benefits and drawbacks of using an ERP system in the internal auditing process. The research methods and literature review utilized in the preparation of this study are discussed in the next section.

\section{Methodology and Literature Reviews}

To achieve the objectives of the study, we relied on previous research in the areas of enterprise resource planning and internal auditing. We collected and analyzed the available literature since 2011. Then we worked to integrate the negative and positive results of the use of resource planning systems in internal auditing in our paper in order to obtain a distinct and unique research. To access the needed data, we used different platform such as Taylor \& Francis online, google scholar, research gate, semantic scholar and we adopted internal audit, ERP, on internal auditing, internal audit as the searched keywords. The following research works show the studies that have been conducted to determine the impact of ERP on internal auditing since 2011: 
Morris (2011), studied the effect of ERP systems on the efficiency of internal controls. The study's findings demonstrated that ERP systems may help improve internal controls as one of the essential features of ERP systems is the utilize of "built-in" controls that reflect the infrastructure of the firm, which is one of the numerous justifications for ERP systems' high price. Firms that use ERP seem to be less likely to disclose internal control problems than organizations that do not use ERP, according to the findings.

Jain and Soral (2011), attempts to understand how an enterprise resource planning (ERP) system affects an audit and an organization's internal control system. They concluded that auditors can perform an effective and fast audit using new audit tools and procedures instead of the traditional procedures and concluded that the overall objective and audit scope do not change in the ERP context. The overall results indicated that the nature and complexity of the ERP system increases system's risks. Auditors should pay attention to the risks involved in an ERP system. They also suggest that auditors must also understand the ERP system very well to perform a proper audit of the client using this system.

Chen et al. (2012), discussed the influence of an ERP system on accountant's role. They found that the role of non-management accountants does not change as much as the management accountant's role after the installation of ERP system. And they concluded that management accountants should take over more administrative functions such as education, training and financial analysis after introducing the ERP system.

Kim et al. (2013), examined whether the implementation of the ERP program had an impact on the lag of the audit report. They concluded that the optimum application of the ERP was negatively associated with the latency of the audit report. However, this unfavorable relationship is only noticeable in the fourth and fifth years following the ERP's first adoption. They also mentioned that while the usage of ERP systems by client companies may assist to lessen the lag in the audit report, it takes time to understand the entire impact of the company's accounting systems.

Tsai and Al (2013), investigated the influence of ERP deployment on internal audit performance in Taiwanese companies. The findings indicate that the environment, which includes an ERP system and auditing software, has a beneficial influence on the functioning of the internal audit department. It also demonstrates that the effectiveness and breadth of ERP deployment results can help to improve internal audit performance.

Singh et al. (2014), argued that visualization techniques in an ERP environment may improve auditor's ability to identify suspicious activities and improve the organization's internal controls system.

Haynes et al. (2016), discover that using an ERP system has a considerable influence on efficiency, fraud risk reduction, knowledge application, and the audit team's credibility. The ERP systems that employ continuous audit functions are the most essential factors in the effective application of fraud reduction approaches.

Elbardan et al. (2016), investigates how well the internal audit function (IAF) keeps its authenticity once ERP controls are installed. The results indicate that the auditors' best way to respond to the implementation of ERP systems changed to compliance for two reasons: first, internal auditors believed that adaptation was compatible with international auditing standards, and second, internal auditors participate in Implementation of ERP. Furthermore, the findings show that ERP systems impose new assumptions. Instead of doing individual audits, Integrated Internal Audit now audits all systems and procedures. Audits may now focus on financial, operational, and IT-related controls and activities all at the same time, thanks to ERP systems. The researchers proposed that practical and scientific rehabilitation of internal auditors is required in order to integrate governance principles and standards in the new ERP environment.

Abdullah (2017), talked about the Finance and Accounting module in the ERP system. The finance and accounting module is within the charge of the whole money/capital input and output. This module records all financial activities such as expenses, financial statements, account general ledger, budgeting, bank statements, cash receipts, payroll processing, and so on. For this ERP module, 
financial statement is a straightforward process. With a single click of the mouse, you may obtain whatever financial data you need to operate your firm.

Al Dhiba et al. (2018), investigated the impact of ERP systems on internal auditing quality in Jordanian commercial banks. They discover that when the ERP system is used in the audit process, the auditor may create and implement relevant control tests and material processes, further protecting the internal from the danger of delivering an incorrect opinion or taking an incorrect action.

Neamah and Hassan (2019), revealed that the use of continuous auditing procedures in firms that use the ERP system helps to build an environment that allows for efficient and effective corporate control. Furthermore, they found that the use of continuous auditing techniques contributes to the creation of competitive advantage for enterprises that implement the ERP system by providing appropriate, reliable, and timely information that enables decision-makers to make the best decisions at the lowest possible cost and in the shortest amount of time.

Faccia et al. (2019), focused in their research paper on the comparison between accounting information systems and the most commonly used ERP systems currently in the United Arab Emirates. They observed that many organizations that had previously used accounting software had switched to an ERP system. According to the report, the rising requirement and demand for real-time information to be utilized in decision-making drove many firms in the UAE to adopt ERP. Hence with the software modules built into ERP, and the ability to integrate AIS systems with it, ERP has proved to be a valuable solution for firms in the UAE to adopt in order to streamline corporate processes. While the implementation and usage of an Enterprise Resource Planning (ERP) system was viewed as a step in the right direction by many firms in the UAE, a number of organizations were hesitant to implement this system. This was due to the perception that it was a system that would result in job losses by automating various tasks. Furthermore, some businesses have determined that it would be costly to deploy and will necessitate the ongoing presence of technology-enabled staff to analyze data for organizational leaders.

\section{Results and Discussion}

Along with the extensive growth of computer systems in businesses. organizations implement different technologies in order to keep competitive advantages in the market. ERP is one of the tools implemented by companies. Companies that implement ERP system, all their information becomes available in a single database which facilitates the audit process for those in charge of it. Imagine the ease of having all the information in one place without having to move from one database to another. Ease of access to data is important, but the most important thing is that the data is secure and not mispresented. The ERP system can be responsible to some extent for data security by turning on the "Prevent Unauthorized Access" feature during system implementation. The studies revealed the importance of the participation of the person responsible for the internal audit in the company in the process of implementing the ERP system.

In addition, the research revealed a change in the role and skill of those responsible for internal auditing during and after the implementation of ERP technology. During implementation, internal auditors need to learn the operational processes of the ERP modules, especially the financial and accounting modules that they will use to perform their duties. After the implementation of ERP, management accountants are responsible for more education, training, and financial analysis than non-management accountants.

Companies that use an ERP system can deal with information more correctly than they could previously, modifying and increasing the quality of accounting and financial operations, which inevitably influences the internal audit process. The results of this study revealed the importance of the ERP system in relation to the efficiency of the daily operations of the company. The accurate and effective completion of the company's daily operations reflects positively on the internal audit process. Internal audit is nothing but a double check on all the previous work. Table 1 bellow presents the pros and cons of the using of ERP in internal audit. 
Table 1: The Pros and Cons of the Using of ERP in Auditing Process

\section{The Pros}

- Thanks to ERP built- in features, ERP improve internal control system and internal audit performance. For instance, visualization techniques In an ERP environment may improve auditor's ability to identify suspicious activities and determine fraud.

- An effective and fast audit processes can be done using ERP system.

- ERP keeps and doesn't change the overall objective and scope of audit.

- Following the implementation of the ERP system, the responsibility of auditors and management accountants shifted to administrative responsibilities like as education, training, and financial analysis.

- ERP systems assist in the reduce of audit report latency.

- ERP systems reduce fraud because it adopts continuous audit functions.

- The use of ERP systems considered compatible with international auditing standards.

- ERP consists of several integrated modules, including the financial module, which enables the auditor to access any financial data and create any financial report he needs with a mouse click.

- ERP enables auditor to make the best decisions at the lowest possible cost and in the shortest amount of time.

- ERP system helps to build an environment that allows for efficient and effective corporate control.

- With its built-in ERP software modules, and the ability to integrate AIS systems with it, ERP has proven to be a system worth using by organizations.

- ERP provides integrated audits rather than separate audits since one of the advantages of ERP is that it is an integrated system that unites all of the enterprise's divisions into one.
- $\quad$ Enterprise Resource Planning (ERP) is a complex system and auditors may need time to fully understand and be able to take advantage of all its features. Therefore, auditors should pay more attention to the risks involved in an ERP system.

- The implementation of ERP system is expensive.

- Use of ERP system requires auditors to be skilled in information technology.

- ERP is a system that may lead to job losses because it automates many jobs.

\section{Conclusion}

Advances in information technology, internet and e-commerce have expanded, and global competition is making running a successful enterprise more difficult than ever. In order to keep pace with the rapid changes in the world, it was necessary to create a specific program that could perform 
all tasks from an accounting point of view. The result is summarized in the creation of ERP. The fundamental goal behind ERP is to centralize all data and allow simple access to it to a wider audience. Companies are using ERP systems and applications more than ever before. Many of these systems create and process information used in preparing a company's financial statements. Auditors rely on the data and reports produced by these systems. In this context, there is a direct link between the ERP system and the audit process and it is crucial to know the impact of the ERP system on the audit. As a result, the primary goal of this research was to ascertain the influence of deploying an ERP system on internal auditing.

This study discovered that the use of ERP system affects the performance of audits. The advantages of using ERP system in the auditing process outweigh its disadvantages, and we presented a table of the pros and cons in the previous section. We have noticed that many disadvantages can be avoided by involving the auditor in ERP implementation process. Internal auditors' participation in the ERP implementation process may have an impact on the internal audit department's performance because internal auditors' participation, experience, requirements, and ability to use information technology are typically regarded as useful for controlling risks, maintenance costs, and audit work (Niu et al., 2013). Furthermore, the researchers proposed that internal auditors receive practical and scientific rehabilitation in order to integrate governance concepts and norms in the new ERP environment. Although a literature review was used as a strategy for this study, it has significant drawbacks. First, some linked publications may have gone unnoticed. A large portion of the material has been scanned by simply reading the title. Although the title usually accurately depicts the substance, this is not always the case. We suggest conducting an applied research to assess the conformity of the pros and cons that we found in this research, and we suggest completing the chain of impact of emerging technological programs on the audit process as future studies.

Yazar Katkı Oranı (Author Contributions): Mehmet Nuri SALUR (\%50), Walaa Khoder KATTAR (\%50)

Yazarların Etik Sorumlulukları (Ethical Responsibilities of Authors): $\mathrm{Bu}$ çalışma bilimsel araştırma ve yayın etiği kurallarına uygun olarak hazırlanmıştır.

Çıkar Çatışması (Conflicts of Interest) : Çalışmadan kaynaklı çıkar çatışması bulunmamaktadır.

İntihal Denetimi (Plagiarism Checking): Bu çalışma intihal tarama programı kullanılarak intihal taramasından geçirilmiştir. 


\section{REFERENCES}

Abdullah, A. M. A. (2017). "Evolution of Enterprise Resource Planning Excel”. Journal of Engineering Technology and Management Science, 1(11). Retrieved from: http://excelpublication.com/index.php/current-issue-8/.

Byrnes, P.E., Al-Awadhi, A., Gullvist, B., Brown-Liburd, H., Teeter, R., Warren, J.D., \& Vasarhelyi, M. (2018). "Evolution of Auditing: From the Traditional Approach to the Future Audit", Chan, D.Y., Chiu, V., \&Vasarhelyi, M.A. (Ed.) Continuous Auditing (Rutgers Studies in Accounting Analytics), Emerald Publishing Limited, Bingley, pp. 285-297. https://doi.org/10.1108/978-1-78743-413-420181014

Cangemi, M. April (2010). Internal Audit's Role in Continuous Monitoring. The EDP Audit, Control, and Security Newsletter, 41(4).

Chandler, A. D. Jr. (1977). The Visible Hand: The Managerial Revolution in American Business. Cambridge, Massachusetts: Harvard University Press.

Chen, H., Yan Huang, S., Chiu, A., \& Pai, F. (2012). "The ERP System Impact on the Role of Accountants”. Industrial Management \& Data Systems, 112(1), pp. 83-101.

Dezdar, S., \& Ainin, S. (2011). "The Influence of Organizational Factors on Successful ERP Implementation". Management Decision, 49(6), pp. 911-926.

Elbardan, H., Ali, M., \& Ghoneim, A. (2016). "Enterprise Resource Planning Systems Introduction and Internal Auditing Legitimacy: An Institutional Analysis". Information Systems Management, 33(3), pp. 231-247.

Faccia, A., Mosteanu, N. R., Fahed, M., \& Capitanio, F. (2019). Accounting Information Systems and ERP in the UAE. Proceedings of the 2019 3rd International Conference on Cloud and Big Data Computing - ICCBDC 2019. https://doi.org/10.1145/3358505.3358509

Haynes, Robin \& Li, Chunyan, (2016). "Continuous Audit and Enterprise Resource Planning Systems: A Case Study of ERP Rollouts in the Houston, TX Oil and Gas Industries". Journal of Emerging Technologies in Accounting, 13(1), pp. 171-179.

IIA (Institute of Internal Auditors). 2005. Corporate Governance. The Institute of Internal Auditors Homepage. Retrieved from https://www.theiia.org/?doc id_1041

Jain, M.M., \& Soral, G. (2011). Impact Of ERP System On Auditing And Internal Control. TIJ's Research Journal of Social Science \& Management - RJSSM, 1.

Kim, J., Nicolaou, A. I., \& Vasarhelyi, M. A. (2013). "The Impact of Enterprise Resource Planning (ERP) Systems on the Audit Report Lag”. Journal of Emerging Technologies in Accounting, 10(1), pp.63-88.

Morris, J. J. (2011). "The Impact of Enterprise Resource Planning (ERP) Systems on the Effectiveness of Internal Controls over Financial Reporting”. Journal of Information Systems, 25(1), pp.129-157.

Nagpal, S., Khatri, S. K., \& Kumar, A. (2015). Comparative Study of ERP Implementation Strategies. 2015 Long Island Systems, Applications and Technology. https://doi.org/10.1109/lisat.2015.7160177

Ogechi, Anyanwu, (2018). The Role of Enterprise Resource Planning Systems in Continuous Auditing of $A$ Selected Organization in the Western. Unpublished Master Thesis in Technology in Business Information Systems in the Faculty of Business and Management Science, University of Technology. 
Ranjan, S., Jha, V. K., \& Pal, P. (2016). "Literature Review on ERP Implementation Challenges". International Journal of Business Information Systems, 21(3), 388402. https://doi.org/10.1504/ijbis.2016.074766

Saleh N.\& Salih Hassan, I. M. (2019). "Activate the Reliability of the Enterprise Resource Planning (ERP) System by Using Continuous Auditing/Exploratory Study in Iraq”. Tikrit Journal of Administration and Economics Sciences, 15(46), pp.1-17. Retrieved from: https://www.iasj.net/iasj/article/167845.

Schenker, J. (2018). Overview of audit - Audit and Due Diligence Foundations. Retrieved from https://www.linkedin.com/learning/audit-and-due-diligence-foundations/overview-of-audit

Schniederjans, D. \& Yadav, S. (2013). "Successful ERP Implementation: An Integrative Model". Business Process Management Journal, 19(2), pp. 364-398.

Singh, K., Best, P. J., Mario, B., \& Blunt, C. (2014). "Continuous Auditing and Continuous Monitoring in ERP Environments: Case Studies of Application Implementations". Journal of Information Systems, 28(1), pp. 287-310.

Wen-Hsien Tsai, Hui-Chiao Chen, Jui-Chu Chang, Jun-Der Leu, Der Chao Chen \& Yuyun Purbokusumo (2013). Performance of the Internal Audit Department Under ERP Systems: Empirical Evidence from Taiwanese Firms. Enterprise Information Systems, https://doi.org/10.1080/17517575.2013.830341. 